\title{
"Insani" Psychotherapy based on Prophet Therapy as an Alternative Solution before Having Vaccines
}

\author{
Retno Anggraini ${ }^{1}$, Wahyudi Widada ${ }^{2}$ \\ Universitas Islam Sultan Agung, Semarang, Jawa Tengah, Indonesia ${ }^{1}$ \\ Universitas Muhammadiyah, Jember, Jawa Timur, Indonesia² \\ \{retno.a@unissula.ac.id ${ }^{1}$, wahyudiwidada@unmuhjember.ac.id²
}

\begin{abstract}
Covid-19 has threatened and changed the world because there is no anti-virus yet, a comprehensive alternative therapy is needed to help people. Indonesia has various kinds of traditional medicine (Battra). Developed countries have integrated it with medical. The research objective: to determine the potential of Prophet Therapy (Nabawi Therapy) as a solution. Method: a qualitative case study. Data: obtained from literature and field studies, involving 12 Battra-themed Whatsapp groups and 30 experts. Result: The study of the qauliyah and kauniyah verses found scientific facts: Prophet Therapy is a form of Integral-Transcendental therapy, consisting of writing Quran, ruqyah, herbs, cupping, prayer \& patience, it is called "Insani" psychotherapy. These therapeutic therapies can maintain health comprehensively - holistically and undoubtedly can be integrated with medical therapy to face pandemics before having vaccines and new life.
\end{abstract}

Keywords: Insani Psychotherapy, Nabawi Therapy, Before the Vaccine

\section{Introduction}

The Covid-19 pandemic is a serious threat to the world as it is expanding to 187 countries, causing serious damage to human health and a huge socio-spiritual burden. Patients or suspected of being infected may react emotionally and display behaviors of fear, boredom, loneliness, incidents, insomnia or, strong anger. Such conditions can develop into disorders, depression, reports, panic attacks and, post-traumatic, psychotic, or paranoid stress. Furthermore, causing Indonesia for the next 2-3 years to face a different life and have to make adaptations. Currently, the Indonesian Ministry of Health has not been able to make anti-virus, vaccine research at WHO is a drug that is specifically approved for clinical treatment is not yet available, except for the vaccine against COVID-19 which is being evaluated and still controversial. Especially for the Muslim community who need a halal and appropriate approach (tayyib). Complete alternative therapy is needed so that the coronavirus does not continue to develop. Developed countries have studied and developed alternative medicine and integrated with medical care. TCM in China has long been synergized with medical treatment. Recent research claims its ability to deal with the Covid-19 pandemic [1]. In addition to undergoing medical treatment, people also choose traditional medicine as an alternative. The choice of traditional therapy as an alternative is mainly because the models of 
these therapies are individual as a whole or are ready to serve and encourage individuals who are active in health care. WHO research in Asia found that the common reasons people use traditional medicine and methods are: easy to reach and accept from a social, cultural, and economic perspective.

The Indonesian Ministry of Health can also play an active role in coaching traditional medicine (Battra) [2], one of which is called Nabawi Therapy. This treatment is based on authentic history in both the verses of the Qur'an and the Prophet's Hadith [3]. Islamic therapy continues to develop, and is integrated with medical therapy, in various parts of the world [4], [5], with standardized applications and tools [6], with SOP [7] as well as the ethics and motivation that underlies charity [8]. Cupping (hijamah) effective in preventing chronic liver disease [9], autoimmune [10] and various diseases with diagnosis and treatment that have long been clinically tested (evidence-based).

The purpose of this study was to determine the potential of Prophet Therapy (Nabawi Therapy) as a solution to facing a pandemic and adapting to new life systems. Uncertain situations and conditions cause stress and depression which leads to various psychosomatic illnesses. This needs to be prevented before there is a truly safe and reliable vaccine, halal and thoyyib (appropriate approach).

\section{Method}

This research is a qualitative case study within the framework of Islamic psychology. This research begins with a literature study (Library Research) to obtain information contained in the Al-Qur'an, Al Hadith, and the Book of Ath Thibb An Nabawi (Prophetic Medicine Methods) and psychology and therapy books, as well as scientific research journals. Researchers are also looking for information in the field about Ath Thibb An Nabawi in theory and practice (via questionnaires, observations, and interviews) involving 12 traditional therapies (Battra)-themed Whatsapp groups and 30 medical experts. The research design in Figure 1.

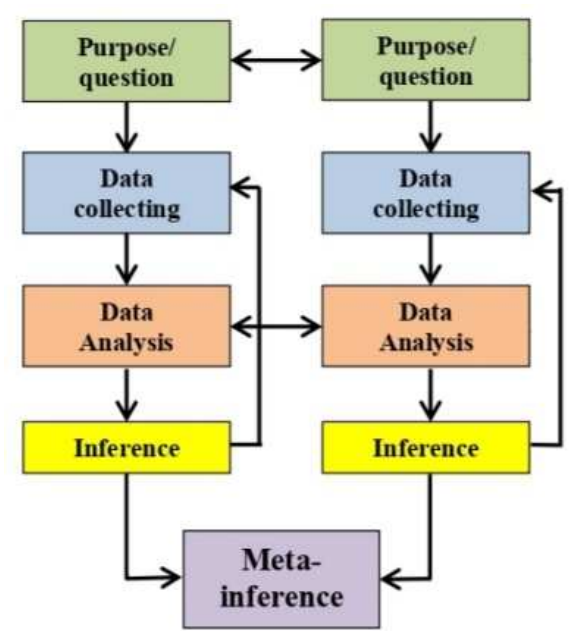

Fig. 1. Research Design "Insani” Psychotherapy Based on Prophet Therapy 


\section{Results and Discussion}

\subsection{Humans Must Adapt to a Pandemi}

The phenomenon of increased stress and depression during a pandemic has resulted in increased poverty, unemployment, death of loved ones or breakups, physical illness and, alcohol and drug problems [11],[12]. No matter how well individuals adjust, all suffer when negotiating transitions, trauma, challenges, and losses. Large and long-term stress will have an impact on performance and efficiency[13]. It can be understood then that WHO declared New Normal as a solution to dealing with the Covid-19 pandemic in an uncertain long term. This requires public health management of the concepts and practices.

Conventional psychologists claim that to deal with stress the individual must learn and have coped with stress, in the form of "all efforts, healthy or unhealthy, conscious or unconscious, to prevent, eliminate, or at least weaken stress triggers, or to tolerate their effects in the most effective way. does not hurt ". However, coping efforts are not always healthy and constructive, they can even worsen the condition to become psychosomatic [14], [15]. The absence of religious and spirit (cultural) factors in health management has the potential to become a problem of failure. A psychological phenomenon is the result of a sequence of meanings of thoughts, actions, feelings, perceptions, and so on, which are arranged based on local (cultural) norms and standards of truth [16]. So we need a clear and precise concept for communities with certain cultures, especially Islamic culture.

\subsection{Health and Therapy Concept in Islam}

Islam has taught healthy ways of life. The information has been given since 14.5 centuries ago through the qauliyah verse, written in the Qur'an (Surah Al-'Alaq / 96: 1-5; Surah Al-Isra / 17: 82). In these verses, Allah has declared himself as Rabb which means educator, preserver, owner, who grows and who perfects. Researchers found important words in the scriptures related to this study and are presented in table 1.

Table 1. The Words (ayat) about Health and Therapy

\begin{tabular}{ll}
\hline Word & Amount \\
\hline Allah & 2,697 \\
Al-Khaliq & 150 \\
Rabb & 969 \\
Al-Alim & 175 \\
Syifa & 6 \\
Hudan & 43 \\
Dhikr & 292 \\
Human & 64 \\
Basyar & 37 \\
Hadith & 32 \\
Gratitude & 75 \\
Ulul albab & 16 \\
Aql & 49 \\
Fiqh & 2 \\
Lesson & 20 \\
Burhan & 20 \\
Ism & 19 \\
Islam, greeting, etc & 73 \\
Apostle & 218 \\
Healthy & 318 \\
\hline
\end{tabular}


There are 94 kinds of practices, in the form of herbs, food, and in the form of worship rituals that the Prophet Muhammad mentioned. Researchers found 16 types that are potentially right to deal with Covid-19 (Table 2).

Table 2. Sixteen of 94 types of therapy for the Prophet SAW, which are integrative and intervene in all aspects of health [17],[18],[3]

\begin{tabular}{|c|c|}
\hline Therapy, medicine & Explanation \\
\hline Al-Quran. & Healer, antidote, and cure for all diseases of the liver and body. \\
\hline Dhab & ma, smooths the skin \\
\hline Faghiyah (Henna) & $\begin{array}{l}\text { Accelerate healing of burns, anti-bleeding, antiviral, heal cracked skin, reduce } \\
\text { infection, as a hair dye }\end{array}$ \\
\hline Hijamah (Cupping) & Medicine, therapy for all diseases, detoxification. \\
\hline Laban & $\begin{array}{l}\text { Moisturizes a dry body provides a good nutritional injection, frees from anxiety, } \\
\text { gloom, and various diseases due to the body's black elements, improves body ions } \\
\text { after intercourse, suitable for sufferers of chest, lung, tuberculosis }\end{array}$ \\
\hline Talh (banana tree) & Treat disorders of the chest, lungs, coughs, kidney and bladder infections \\
\hline Asal (honey) & $\begin{array}{l}\text { Prevent cancer and heart disease, as antibacterial and antifungal, to improve athletic } \\
\text { performance, reduce cough and throat irritation, regulate blood sugar }\end{array}$ \\
\hline $\begin{array}{l}\text { Halibutl Maeiz (goat } \\
\text { milk) }\end{array}$ & $\begin{array}{l}\text { It is gentle and neutral, can relax the abdominal muscles, moisturize the dry body, treat } \\
\text { sore throat, dry cough, and bleeding. }\end{array}$ \\
\hline $\begin{array}{l}\text { Safarjal (a type of } \\
\text { guava, Quince) }\end{array}$ & $\begin{array}{l}\text { Reducing Hypertension, Overcoming Diabetes, Healthy Thyroid, Optimizing Vision, } \\
\text { As a medicine for fever and cough, for skincare. }\end{array}$ \\
\hline Sahm (Tallow) & throat disorders, hoarseness, treats intestinal infections \\
\hline Kam'ah (Truffle) & $\begin{array}{l}\text { muscles, improve blood circulation, relieve headaches, prevent } \\
\text { at }\end{array}$ \\
\hline Rumman (pomegranate) & $\begin{array}{l}\text { Relieve arthritis pain and joint pain, lower blood pressure, Improve immunity, Fight } \\
\text { viral and bacterial infections, Keep hunger at bay, Prevent cancer, Lower the risk of } \\
\text { Alzheimer's disease, Increase sex drive and fertility }\end{array}$ \\
\hline Shalat (prayer) & $\begin{array}{l}\text { Avoiding the human body from disease attacks, Increasing the activity of one's limbs } \\
\text { and mental health, Eliminating heart disease in others and its dinginess means to ask } \\
\text { Allah for help to get the good of the world and the hereafter. }\end{array}$ \\
\hline Shabr (patience) & $\begin{array}{l}\text { Adaptation will be easier, Very Tolerant to Frustration, Reduces the bad effects of } \\
\text { stress, It is more difficult to fall ill, Helps individuals to see opportunities more clearly }\end{array}$ \\
\hline Shaum (Fasting) & $\begin{array}{l}\text { Detoxification, Resting the Digestive System, Overcoming Inflammation, Reducing } \\
\text { Blood Sugar, Helping Overcome Obesity, Hypertension, Healthy Diet }\end{array}$ \\
\hline $\begin{array}{l}\text { Syuniz (Al-Habbah As- } \\
\text { Sauda, Black seeds) }\end{array}$ & $\begin{array}{l}\text { Strengthens the immune system from viruses, germs, and bacteria, Defends the body } \\
\text { from cancer and HIV, improves brain function, cures various types of respiratory } \\
\text { diseases, overcomes sleep disorders and stress, as an antihistamine \& allergy }\end{array}$ \\
\hline
\end{tabular}

Those verses are guarantee from the Most Merciful. And when I am sick, He is the One Who heals me (Surah Asy-Syu'araa ': 80); The Qur'an relieves the hearts of those who believe (Surah At-Taubah: 14); a healer for diseases (which are) in the chest (Surah Yunus: 57); be an offer and a mercy for those who believe (Surah Al-Israa ': 82; guidance and bidder for believers (Surah Fussilat: 44). Humans who obey God's command will have sufficient knowledge to face life's problems, tense, terrible changes, and demands adjustment. Reading has a broad meaning, namely all activities that are usually carried out by a scholar and scientist in discovering truths from within his religion and in all of His creation. This understanding leads to the right approach to human problems that is integral and transcendental.

Al Ghazali since centuries ago has explained about the soul and its dynamics, about mental illnesses that originate from the damage or illness of the heart, aql, and the body as well as external disturbances due to a way of life that conforms to the nafs. He also explained the ways to heal the soul. This knowledge has inspired the world to behave in a healthy body and soul through increasing engagement with the Qur'an [18]. This knowledge has until now 
become an important reference, continued and refined by subsequent scientists because of its relevance to this era. Ruqyah research is useful in cases dealing with viruses and damage to immunity such as HIV / AIDS in addition to metaphysical cases [9]. Likewise the findings of Indonesian scientists in terms of Islamic spirituality [20], wrote the Qur'an for character education [21], a content in counseling guidance [22]. Praying with Qs. Ar-Rahman has proven useful in dealing with life's pressures [23]. Listening to the Qur'an with tartil promote mental health and calmness [24]. Research reviews on 973 articles and 28 experimental trials provide an overview, reciting the Koran can be useful as a non-pharmacological therapy to reduce anxiety in various life events. So it can be said that religion is an important socioemotional resource, and one of the most beautiful aspects of the miracle of the Qur'an is the human voice when reading the Qur'an [25].

Carry out the command "iqra", which means to examine, understand, know the characteristics of something, read nature, read the signs of the times, history, self, written and unwritten. The iqra $\sim$ command object includes everything readable and should be read. $A I-$ Qur'an emphasizes the importance of science and technology to create a healthy and happy civilization along with a healthy human identity, by guiding life, by cleansing the mind and purifying the soul; guide and teach socialization and national life; getting rid of poverty, ignorance, suffering, and injustice; integrating truth and justice with mercy and compassion. Reading it and listening to it is psychologically beneficial [26]. Moreover, Allah himself has stated that the Qur'an is syifa (medicine) in which it informs various plants, fruits, animals, and substances that can be researched scientifically. Rasulullah Saw. also stated that hijamah is a therapy for all diseases except aging and death.

\subsection{Islamic Stress Coping}

Literature research through tracing qauliyah and kauniyah verses get scientific facts in the form of basic concepts of Nabawi Therapy. Nabawi Therapy since being inherited by the Prophet continues to be used and developed in many countries with various climates, cultures, and religions. Ideally, Nabawi Therapy has the task of educating, developing, building character, maintaining the health of the nafs-jazadiyah (psycho-soma), developing faith, and saving spiritual to achieve a healthy heart. As Islamic psychotherapy, the approach uses scientific-objective reasoning optimally with the right methodology, referring to the formal sources of the Qur'an and Sunnah or the views of scholars (scientists) who are praiseworthy (amanah and sahih) [27],[28]. Healthy individuals are wal'afiat with various balances (mizan) of growth, as well as the optimal development of various natural potentials that are bestowed by Allah. Muslim scientists have formulated a healthy concept covering the integrative dimension, namely the psychological / psycho-organo-biological, social, and spiritualreligious dimensions. There involve psychoneuroimmunological mechanisms [29],[30]. The foundation of the Integral-Transcendental paradigm becomes its main characteristic.

Old literature and empirical research on stress obtained four categories. First, individuals choose to fight with the pressure of reality and try to strive to achieve the things they want. Second, the individual decides to run away from things that make him feel stressed. Third, individuals can reduce stress through social activities and religiously oriented activities. This shows when the individual decides to accept life as it is and realizes that everything has been arranged and in God's power. At that time a person will be said to have positioned himself as an adaptable human being and has the potential to be happier. Ways to avoid the mental or soul from various symptoms of mental disorders (neurosis) and mental illnesses (psychosis) are: first, the most ideal resolution of conflicts between the physical (material) and the 
spiritual-religious aspects is to compromise both. Fulfilling physical needs within the limits of the Shari'ah, as well as meeting the spiritual needs of religion. Second, the balance that is fulfilled will form a perfectly healthy human, with a strong spiritual-religious personality and high physical vitality. Third, the concept of human balance in various forces and bodilyspiritual functions is a reflection of the balance in the universe. The human task is to protect it [31],[32].

Ibnu Qayyim Al Jauziyah mentions four complementary things regarding individual health education and public health. At the individual level, education is given in terms of: first, maintaining body hygiene (ablution practice, skin cleanliness, oral hygiene, sunnah fitriah), and others. Second, to prevent bodily diseases by adjusting food consumption patterns (fasting, exercising). Third, seek treatment with a medicine that is the lawful, good, halal, and appropriate approach (thayyib). Fourth, improve faith and understand its medicine effects. At the environmental and community level, education is given in terms of: first, paying attention to environmental cleanliness and guarding it against dirt, cleaning roads and public places, and avoiding dogs except for emergencies. Second, pay attention to and be careful of the means or media for disease transmission, especially sterilization of air, water, and food. Third, maintaining health by preventing the spread of diseases, such as avoiding oneself $\left(\mathrm{al}-{ }^{\prime} \mathrm{Azl}\right)$ and using sterile washing equipment. Fourth, the prohibition of some types of food, drink, and sexual deviation.

Reviews of Nabawi Therapy especially cupping or hijamah in vitro, in vivo and clinical get scientific evidence of its efficacy as anti-tumor, antimetastatic, antiangiogenic, antiproliferative, chemopreventive and neo-adjuvant [33]. This theraphy can overcome various diseases with diagnosis and treatment that has long been clinically tested (evidence-based). Nabawi Therapy includes therapy using plants, food ingredients, or spices that are used as prescription drugs and nutritional intake. Islamic therapy continues to develop and is integrated with medical therapy, in various parts of the world [34],[35] and standardized [36] with SOPs [37]. Systematic review studies and meta-analyses show that wet cupping is a safe therapy [38],[39].

\subsection{Prophetic Therapy in Communities}

Communities in several areas in the Arabian Gulf have practiced Traditional Arabic Medicine and Islamic Medicine (TAIM) for thousands of years, consisting of herbal medicines, spiritual healing, dietary practices, mind-body methods, and manual techniques, applied singly. or in combination, as needed. Its prevalence is increasing. Nabawi Therapy is an inherited science recommended by the Prophet Muhammad, meaning that there are ancient medical sciences that are prohibited, namely those containing shirk (syirik) and haram substances. So the principles of natural medicine then become part of the culture and are often practiced simply to mutually respond to members of a family of people all over the world who have ever known Islamic culture. Even though in the 17th and 18th centuries they became marginalized due to the advancement of modern medicine, but now they are gaining popularity again and are supported by many scientific kinds of researches

As a traditional therapy, of course, there are differences in the way it is practiced professionally in hospitals today. History has recorded that inherited knowledge has been beneficial to society for a long time and has even progressed along with health science. Even when the Covid-19 pandemic was announced by WHO, many scholars or da'i told about the methods that were practiced when the Tha'un outbreak occurred in the era of the Prophet's companions. In Indonesia, there is an ancestral heritage herbal therapy science that is 
increasingly popular in WhatsApp groups, namely: empon-empon (red ginger, ginger, prickly turmeric, cinnamon, and lemongrass), oranges, and their peels which have been studied by IPB (Institute Pertanian Bogor) and UI (Universitas Indonesia) contain flavonoids and hesperidin. Guava because they contain hesperidin, rhamnetin, kaemferol, quercetin, and myricetin. Another herb is Moringa leaves, which in the past were known as plants for the therapy of metaphysical problems destroying immune science and very good for increasing breast milk, nowadays it is also increasingly favored by the public. These herbs and several other herbal products licensed by the BPOM are believed to increase immunity and prevent the Covid-19 case from getting worse. WA groups of Nabawi Therapy practitioners and experts can be said to discuss it every day.

Although some doctors state that the information about traditional therapy is new in the form of claims and needs further research, people increasingly believe that alternative approaches to using traditional therapies are beneficial for improving or maintaining health. This is especially so in times of a pandemic that is full of confusing and worrying information. Even the International Islamic Medicine Foundation (IIMF) added information about several hospitals in Indonesia that have been providing traditional herbal therapy services professionally for quite a long time, namely: Yogyakarta: Rajawali Citra Hospital, Nur Hidayah Hospital; Central Java: Roemani Hospital, Sultan Agung Hospital Semarang, Salatiga Holistic Hospital; East Java: Bondowoso Hospital, Siloam Hospital Surabaya; Sulawesi: Wahidin Hospital Makassar.

This qualitative study provides an overview of the Integral-Transcendental therapy model. "Insani" psychotherapy in this study is different from conventional psychotherapy, nor is it just a traditional therapy from Arabic culture because Arabic therapy is not necessarily all Islamic. "Insani" psychotherapy is the specific psychotherapy that utilizes the inherited knowledge of the Prophet Muhammad which is carried out based on the understanding of divine verses as well as true scientific findings. -truly science that can be obtained from all corners of the world (ayat kauniyah), not pseudoscience, because pseudoscience can contradict the faith and it is dangerous.

The studies mentioned in this paper each have limitations in methodology and are less heterogeneous, but inspiring enough to carry out more extensive and in-depth research. Islam and its culture have historically been the source of various modern sciences. Islamic scientists became the founders of medical science in Arabia, Europe, and the world. Complex medical phenomena, such as hydrocephalus, measles, and chickenpox, as well as several surgical instruments, such as catheters, cautery, forceps, clamps and scalpels, and psychology, are the work of Muslim scholars. Even so, the health world is currently determining research work as a way to find new treatments for increasingly complex diseases such as the coronavirus. Facing these challenges, it is necessary to carry out continuous research that is socialized in classy journals, by maintaining the standard of science that is Integral-Transcendental, scientific as well as divine, the history and expectations of the world and the task of creation.

\section{Conclusion}

First, Quran therapy, ruqyah, herbs, cupping, prayer \& patience, are varieties of Nabawi Therapy and are a model of "Insani" Psychotherapy. Can maintain health comprehensively and holistically because it handles health in all aspects: psychological, physiological, sociospiritual-religious. Second, the various scientific findings that have been put forward to confirm that secularity in the health sector with religion is unrealistic and irrational for 
religious communities, especially Indonesia. Third, public awareness about Covid-19, which is still a threat and there is no reliable vaccine, needs to be accompanied by community-based cultural, spiritual-religious, psychological programs.

\section{Recommendation}

The explanation in advance shows that the health science inherited by the prophet through the scholars does not contradict conventional health science so that the authorities and the public need not hesitate to make Islamic Thibb or plant therapy as an integrated program to face the waiting period of a halal and good vaccine. "Insani" psychotherapy can undoubtedly be integrated with medical therapy to deal with a pandemic and a new life system that demands adaptation, so that new, possibly more terrible diseases can be prevented from occurring. For this reason, support from Yankestrad - Dinas Kesehatan - RI Ministry of Health is needed, through realistic-objective-rational-proportional understanding and attitudes. Evidence-based research as behavioral and clinical therapy and adequate socialization must be carried out intensively so that the science of Nabawi Therapy is more developed and useful.

\section{Acknowledgments}

Our gratitude to Sultan Agung Islamic University for providing facilities and support.

\section{References}

[1] Shi xin Wang and others, 'Diagnosis and Treatment of Novel Coronavirus Pneumonia Based on the Theory of Traditional Chinese Medicine', Journal of Integrative Medicine, 18.4 (2020), 275-83<https://doi.org/10.1016/j.joim.2020.04.001>.

[2] RI, Kemenkes, "Peran Penting Terapi Tradisional", Materi Acara Litbangkes (Penyuluhan Battra Yogya), (08 April 2019). Yogyakarta

[3] Sheikh, Bassem Y., Md. Moklesur Rahman Sarker, Muhamad Noor Alfarizal Kamarudin, and Amin Ismail, 'Prophetic Medicine as Potential Functional Food Elements in the Intervention of Cancer: A Review', Biomedicine \& Pharmacotherapy, 95 (2017), 614-48<https://doi.org/10.1016/j.biopha.2017.08.043>

[4] Alrowais, Norah A., and Nada A. Alyousefi, 'The Prevalence Extent of Complementary and Alternative Medicine (CAM) Use among Saudis', Saudi $\begin{array}{llll}\text { Pharmaceutical Journal, 2017.25 306-18 } & \text { (2017), }\end{array}$ $<$ https://doi.org/10.1016/J.JSPS.2016.09.009>

[5] Al-Bedah, Abdullah M.N., Ibrahim S. Elsubai, Naseem Akhtar Qureshi, Tamer Shaban Aboushanab, Gazzaffi I.M. Ali, Ahmed Tawfik El-Olemy, and others, 'The Medical Perspective of Cupping Therapy: Effects and Mechanisms of Action', Journal of Traditional and Complementary Medicine, 9.2 (2019), 90-97 $<$ https://doi.org/10.1016/j.jtcme.2018.03.003>

[6] Aboushanab, Tamer, and Saud AlSanad, 'A Brief Illustration of the Official National Standards for the Safe Use of Cupping Therapy (Hijama) in Saudi Arabia', Journal of Integrative Medicine, 16.5 (2018), 297-98 $<$ https://doi.org/10.1016/J.JOIM.2018.07.006>

[7] AlRawi, Sara N., Amal Khidir, Maha S. Elnashar, Huda A. Abdelrahim, Amal K. Killawi, Maya M. Hammoud, and others, 'Traditional Arabic \& Islamic Medicine: Validation and Empirical Assessment of a Conceptual Model in Qatar', BMC 
Complementary and Alternative Medicine, $17.157 \quad$ (2017), $1-10$ $<$ https://doi.org/10.1186/s12906-017-1639-x>

[8] Perkumpulan Bekam Indonesia, Tim Diklat dan Litbang Pusat, Panduan Pengajaran Bekam (Jakarta: Perkumpulan Bekam Indonesia, 2019)

[9] Homayoon Bashiri, Arezoo Bozorgomid, and Vahid Shojaeimotlagh, 'Efficacy of Hijamat (Wet Cupping Therapy) in Iranian Patients with Nonalcoholic Fatty Liver Disease: A Controlled Clinical Trial', Turkish Journal of Medical Sciences, 50.2 (2020) <https://doi.org/10.3906/sag-1907-82>.

[10] Hussam Baghdadi and others, 'Ameliorating Role Exerted by Al-Hijamah in Autoimmune Diseases: Effect on Serum Autoantibodies and Inflammatory Mediators', International Journal of Health Science, $2015<$ https://doi.org/10.12816/0024129>.

[11] WHO-Europe, 2020. WHO_Europe Coronavirus disease (COVID-19) outbreak Mental health and psychological resilience during the COVID-19 pandemic. [online] WHO Europe. Available at: <http://www.euro.who.int/en/health-topics/healthemergencies/coronavirus-covid-19/news/news/2020/3/mental-health-andpsychological-resilience-during-the-COVID-19-pandemic>.

[12] Saleh Baqutayan, Shadiya Mohamed, 'Stress and Coping Mechanisms: A Historical Overview', Mediterranean Journal of Social Sciences, 6.2S1 (2015), 479-88 $<$ https://doi.org/10.5901/mjss.2015.v6n2s1p479>

[13] Stuart, Gail W, 'Buku Saku Keperawatan Jiwa' (Jakarta: EGC, 2019)

[14] Hawari, D. (2006). Manajemen stres, cemas dan depresi. Jakarta: Fakultas Kedokteran Universitas Indonesia.

[15] Harré, Rom, 'Positioning Theory: Moral Dimensions of Social-Cultural Psychology', Oxford Handbooks Online, March 2012, 1-25 $<$ https://doi.org/10.1093/oxfordhb/9780195396430.013.0010>

[16] Ibnu Qayyim Al-Jauziyah. (2015). The Prophetic Medicine (Metode Pengobatan Nabi) (Indonesia; T. G. Ilmu, ed.). Jakarta: GRIYA ILMU.

[17] Iqtedar, Mohammed, Husain Farooqi, Phoenix Linn, Olea Linn, Vitis Linn, and Sweet Basil, 'List of Quranic and Prophetic Plants', in Medical Plants in The Traditions Of Prophet, 4th edn (Sidrah Publishers), pp. 1-5 $<$ http://www.sabawoon.com/articles/pages/Quranic_Prophetic_Plants_2013.pdf $>$

[18] Abū Ḥāmed Muḥammad ibn Muhammad Ghazali, 'Thya Ulumuddin: Menghidupkan Ilmu-Ilmu Agama (Terjemah Ismail Yakub)' (Medan: Imballo, 1965), p. 1197.

[19] Haslinda Lukman, Latifah Abd Majid \& Wan Nasyrudin Wan Abdullah, 'Kesan Terapi Ruqyah Dalam Merawat Pesakit HIV/AIDS', Al-Hikmah, 7.1 (2015), 119-31

[20] Wika Hanida, E Mudjaddid, Habibah Hanum Nasution, Hamzah Shatri, 'Korelasi Aspek Spiritual Dengan Kadar Interleukin-6 Serum Pada Pasien Hemodialisis Kronik', Jurnal Penyakit Dalam Indonesia, 3.1 (2016), 3-7

[21] Hadi Mas'ud, Konsep Qur'an Tulis, Iqro' Bil Qolam, ed. by Laboratorium Pendidikan Tarbiyatul 'Alamin, Petunjuk d (Mojokerto: Sumber Citra Lestari, 2016)

[22] Desi Alawiyah \& Iin Handayani, 'Penanaman Nilai Spiritual Dalam Dimensi Psikoterapi Islam Di PP. Rehabilitasi Salafiyah Syafi'iyah Nashrun Minallah', KONSELI: Jurnal Bimbingan Dan Konseling (E-Journal), 6.1 (2019), 23-32

[23] Rafique, Rafia, Afifa Anjum, and Shazza Shazdey Raheem, 'Efficacy of Surah AlRehman in Managing Depression in Muslim Women', Journal of Religion and Health, 58.2 (2019), 516-26 <https://doi.org/10.1007/s10943-017-0492-z> 
[24] Mahjoob, Monireh, Jalil Nejati, Alireaza Hosseini, and Noor Mohammad Bakhshani, 'The Effect of Holy Quran Voice on Mental Health', Journal of Religion and Health, 55.1 (2016), 38-42 <https://doi.org/10.1007/s10943-014-9821-7>

[25] Ghiasi, A. , Keramat, A., 'The Effect of Listening to Holy Quran Recitation on Anxiety: A Systematic Review', Iranian Journal of Nursing and Midwifery Research, 23.6 (2018), 411-20<https://doi.org/10.4103/ijnmr.IJNMR_173_17>

[26] Muhammad Chirzin, 'Berinteraksi Dengan Al-Quran', Insyirah, Jumal Ilmu Bahasa Arab Dan Studi Islam, 1. 2 (2013), 75-100

[27] Najati, Muhammad Usman, Al-Qur'an Wa 'Ilm Al-Nafs, ed. by Ahmad Rofi'i (Bandung: Penerbit Pustaka, 2001)

[28] Najati, Muhammad Usman, Psikologi Dalam Perspektif Hadis (Al-Hadits wa "Ulum an Nafs) (Jakarta: Pustaka Al Husna Baru, 2004)

[29] Hawari, Dadang, Manajemen Stres, Cemas Dan Depresi (Jakarta: Fakultas Kedokteran Universitas Indonesia, 2006)

[30] Suwito, Joko, 'Paradigma Psikoneuroimmunologi : Doa Al-Fatihah Mendukung Fungsi Imunitas Melalui Modulasi Endorphin Dan Serotonin Dalam Menghadapi Pandemi Covid-19', IIMF, 2020, 1-19

[31] Esposito, Islam The Straight Path, Oxford University Press., Fifth (New York, 2016), V < https://doi.org/10.1038/104599a0>

[32] Ibnu Qayyim Al-Jauziyah, The Prophetic Medicine (Metode Pengobatan Nabi), ed. by Tim Griya Ilmu, Indonesia (Jakarta: GRIYA ILMU, 2015)

[33] Sheikh, B. Y., Sarker, M. M. R., Kamarudin, M. N. A., \& Ismail, A. (2017). Prophetic medicine as potential functional food elements in the intervention of cancer: A review. Biomedicine $\& \quad$ Pharmacotherapy, 65, 614-648. https://doi.org/10.1016/j.biopha.2017.08.043

[34] Alrowais, Norah A., and Nada A. Alyousefi, 'The Prevalence Extent of Complementary and Alternative Medicine (CAM) Use among Saudis', Saudi $\begin{array}{llll}\text { Pharmaceutical Journal, 2017.25 306-18 } & \text { (2017), }\end{array}$ $<$ https://doi.org/10.1016/J.JSPS.2016.09.009>

[35] Mohamed El Sayed, Salah, Abdel-Salam Al-quliti, Hany Salah Mahmoud, Hussam Baghdadi, Reham A. Maria, Manal Mohamed Helmy Nabo, and others, 'Therapeutic Benefits of Al-Hijamah: In Light of Modern Medicine and Prophetic Medicine', American Journal of Medical and Biological Research, 2.2 (2014), 46-71 $<$ https://doi.org/10.12691/ajmbr-2-2-3>

[36] Aboushanab, Tamer S., and Saud AlSanad, 'Cupping Therapy: An Overview from a Modern Medicine Perspective', Journal of Acupuncture and Meridian Studies, 11.3 (2018), 83-87<https://doi.org/10.1016/j.jams.2018.02.001>

[37] Aboushanab, T., \& AlSanad, S. (2018). A brief illustration of the official national standards for the safe use of cupping therapy (Hijama) in Saudi Arabia. Journal of Integrative Medicine, 16(5), 297-298. https://doi.org/10.1016/J.JOIM.2018.07.006

[38] Lu, Shuting, Shizheng Du, Anne Fish, Cong Tang, Qingqing Lou, and Xuefang Zhang, 'Wet Cupping for Hypertension: A Systematic Review and Meta-Analysis', Clinical and Experimental Hypertension, 2018, 1-7 $<$ https://doi.org/10.1080/10641963.2018.1510939>

[39] Mahmoud, Hany Salah, Moustafa Abou-el-naga, Nassar Ayoub, Abdelatif Omar, Hany Ali El-ghazzawy, and Yasser Mohamed Fathy, 'Alternative \& Integrative Medicine Anatomical Sites for Practicing Wet Cupping Therapy ( Al-Hijamah ): In Light of 
Modern Medicine and Prophetic Medicine', 2.8 (2013), 1-30 $<$ https://doi.org/10.4172/2327-5162.1000138> 